MAŁGORZATA BANASIAK

Wydział Filozofii i Nauk Społecznych

Forum Pedagogiczne

Uniwersytet Mikołaja Kopernika

$9(2019) 2$, cz. 2

Wpłynęło: 05.10.2019

Toruń

ORCID ID: https://orcid.org/oooo-ooo1-9732-6178

AGATA WOŁOWSKA

Wydział Filozofii i Nauk Społecznych

Uniwersytet Mikołaja Kopernika

Toruń

ORCID ID: http://orcid.org/oooo-0oo3-1864-3920

\title{
DEMENTAGOGY: NON-PHARMACOLOGICAL FORMS OF SUPPORT FOR PEOPLE WITH DEMENTIA
}

\begin{abstract}
The article presents quite a new part of pedagogical sciences - dementagogy. The exploratory goal of the article is to indicate new areas of research within special pedagogy that refer to dementagogy and new challenges that aging societies pose to educators. Facilitation strategies directed at people with dementia is one of the challenges but also a great option for non- pharmacological forms of support. The main objective of dementagogy is accompanying a person with dementia in the process of painful parting with oneself and supporting this person in the difficult process of the disease. In the article you will find selected methods of non-pharmacological support for patients with dementia such as Cognitive therapy - RehaCom, Reminiscence therapy, Music therapy, Relaxation, Validation therapy, Occupational and movement therapy, Environmental therapy. Art therapy, Self Maintenance Therapy.
\end{abstract}

Keywords: dementagogy; special geragogy/gerogogy; the elderly; Alzheimer; therapy; non-pharmacological support methods.

\section{Introduction}

Aging societies is an issue of concern for many countries around the world. Due to a longer lifespan we face more age-related conditions. Dementia is an ever-growing problem of patients visiting their family doctors but it also frequents residents of nursing homes. An important but underestimated part of special pedagogy 
is gerogogy, and more precisely its new subdiscipline, pedagogy of people with dementia.

"In view of the biologically conditioned degenerative processes occurring in aging and elderly people, in the face of increasing loneliness and isolation, in the face of a significant dependence on the external world and an unknown environment, there is the same therapeutic and pedagogical responsibility which is undertaken in order to stimulate the development of children and youth with disabilities or at risk of disability." (Bachmann, 1990, p. 89)

The exploratory goal of the article is to indicate new areas of research within special pedagogy that refers to dementagogy. The practical aim is to describe non-pharmacological support methods that can be used in therapeutic work with patients with dementia. The rationale for this paper is to address the missing gap in dementia therapy.

The research method used in this paper is the analysis of professional literature (books, articles, research results, interviews with therapists) and internet resources. The article provides the review of non-pharmacological support methods used in various countries when working with people with dementia and the research indicating the effectiveness of the impact of the methods listed on particular spheres of life of the target group.

\section{Dementagogy}

The traditional geragogy has been focused so far on a normally aging person. The beginning of our century clearly draws our attention to the social issues of the elderly, which is reflected in the creation of special geragogy, whose subdiscipline is the pedagogy of people with dementia - dementagogy (Zych, 2014).

This relatively new area of science under the name of geragogy was created in relation to the fact that the great majority of methods supporting people with dementia is strictly connected with special pedagogy. This term understood as "education of aging and old people" was also used in 1952 by F. Kehrer (Szarota, 2014). Then, Steurenthaler, a German educator and psychologist, suggested using the term dementagogy. According to Steurenthaler (2012), the main aim of dementagogy is to accompany a person with dementia in the process of painful parting with oneself and supporting this person in the difficult process of the disease. The support is understood as providing care and various forms of support both to the patient and their immediate family. The notion of dementagogy appeared also during the European Year of Brain (2014), where the vision of promoting a dementia-friendly society was presented (Zych, 2014). Thus, the introduction of the notion of dementagogy, that considerably increases the field of spatial pedagogy, seems to be sensible due to the growing number of patients with different kinds of dementia, and consequently, the necessity of both therapeutic and research activities in this area. 


\section{Dementia}

Over the years, several definitions of dementia (in Latin. dementia) have been formulated. According to the International Statistical Classification of Diseases and Related Health Problems ICD-10, dementia is a syndrome caused by brain disease, usually of chronic or progressive nature, in which the following cortical functions (cognitive functions) are impaired: memory, thinking, orientation, understanding, numeracy, learning capabilities, language and assessment. ${ }^{13}$ The experts of the World Health Organisation (WHO) state that the basic diagnostics criteria of dementia include disorders of memory and other cognitive functions, i.e. thinking, assessment, planning, organising and general information processing disorders. Although "spatial awareness" is preserved, there may occur the decrease of emotional control over motivation or a change in social behaviour demonstrated as affective lability, i.e. emotional instability, irritability and mood disorders, apathy, euphoria or dysphoria, as well as primitivisation of social behaviour. The described symptoms are usually present for the period of at least 6 months. According to DSM-IV classification, dementia is a syndrome of disorders in cognitive processes, comprised of, apart from memory disorders, deficits of at least two of the following functions: speech (aphasia), purposeful complex movement actions (apraxia), the ability to recognise and identify objects (agnosia) and disorders of planning, initiating, controlling and correcting the course of complex behaviour (executive functions disorders). Cognitive deficits are so deep that they impair professional activity, social functioning and the performance of everyday activities (DSM-IV, 2012).

The dementia process starts with the mild occurrence of difficulties in the areas mentioned above, followed by a gradual deterioration of cognitive functions (Kaplan, Sadock \& Sadock, 2001, p. 43). Various forms of dementia include frontotemporal dementia, dementia in Parkinson disease, dementia with Lewy bodies and dementia in Alzheimer's disease.

The literature describes different forms of support provided to patients with dementia. The researchers suggest that pharmacological treatment is not sufficient to prolong independent functioning of patients. Alternative and supplementary support approaches may or even should be used (Borzym, 2010). They emphasise that some behaviour that mimics care, can harm the patient. Here, we should mention the incorect methods care provision, namely, overprotection and negligence; these two forms may lead to the situation when the patients will function below their capabilities.

According to Borzym (2010), the behaviour of the person with dementia depends on the progressive changes within the brain. In connection with the fact that the

13 ICD-10 Classification of Mental and Behavioural Disorders. Institute of Psychiatry and Neurology.

Vesalius. Kraków-Warszawa (1998). 
changes lead to worsening memory and other cognitive processes, they cause at the same time growing difficulties in understanding the reality surrounding the patient. Therefore, it is necessary to implement various kinds of activities activating the person with dementia, the aim of which is to stimulate existing cognitive abilities. They are to help in maintaining practical skills, improve well-being and alleviate behavioural disorders. The choice of activities shall be individual and shall depend on the stage of dementia as the best results can be achieved by using exercises based on the skills that are relatively well preserved and, at the same time, requiring the patient's engagement (Długosz-Mazur, Bojar \& Gustaw, 2013).

Dementagogy is a very important part of special pedagogy and sets new roles in the work of educators. Pedagogy is not confined to educating children but also grown-up people, including those with dementia. The non-pharmacologicalal interventions is not a task for physicians who prefer drug treatments, but for educators, social workers and psychologists.

\section{Selected methods of supporting patients with dementia}

Among various kinds of support possible to implement in dementagogy, the following ones can be distinguished: RehaCom cognitive therapy, reminiscence therapy, validation therapy, music therapy, movement therapy, occupational therapy, environmental therapy and art therapy. Self-Maintenance Therapy is a very interesting complex therapy for dementia patients. All those forms of therapeutic influence are the elements of dementagogy and they refer to professional activities and accompanying the person with dementia or the person suffering from Alzheimer's disease. Whichever therapy method is chosen, the daily routine is very important in the procedures with a dementia patient. Any deviations from the routine should be avoided as they can increase the patient's anxiety (Kłoszewska, 2012).

\section{Cognitive therapy - RehaCom}

Cognitive therapy - RehaCom is a kind of computer-assisted rehabilitation of cognitive functions. It is an example of a non-pharmacologicalal form of therapy, whose aim is to improve patients' performance with all kinds of brain cognitive functions disorders. This aim is achieved by designing special, patient-friendly re-educational programmes. RehaCom has a module structure (it consists of over 20 modules) and can be configured to meet the patients' capabilities and adjusted to their individual needs, which, in turn, enables improvement of their brain functions. With the use of this method, children and adults can be diagnosed and their cognitive abilities such as verbal and non-verbal memory, attention, concentration, logical thinking, problem solution abilities, memory and face recognition, visual and movement coordination, planning functions and cognitive functions after stroke or cerebral hemorrhage can be trained (HASOMED, 2018). RehaCom can 
be used particularly for children with ADD (attention-deficit disorder), ADHD (attention-deficit/hyperactivity disorder) and learning difficulties. This form of therapy is also recommended and very effective in case of children and adults with cognitive functions disorders caused by focal or general brain damage. The main advantage of the RehaCom therapy is the fact that the system has the function of autoadaptation to the patients' abilities, and it ensures continuity and effectiveness of the training as well as positive motivation of the patients.

\section{Reminiscence therapy}

Another important type of nondrug therapy is reminiscence therapy. It consists in recalling memories with the use of stimulating materials. The prompts used for the therapy can include photographs, keepsakes, smells, music or visits to familiar places. In case of difficulties in remembering current matters, reminiscing gives the patients the sense that they still remember well a lot of things and the disease did not affect each aspect of their memory. Recalling positive memories also causes the improvement of well-being and positive attitude to life. Strictly speaking, the reminiscence therapy influences the psyche of the patient by facilitating a recall of the most important personal experiences, consisting in a stimulation of brain areas connected with so called "memory anchors", i.e. memorised and reiterated memories, which alleviates behaviour disorders and can improve memory and space orientation. Therapists who use this method claim that patients can reach back to their past experiences when they could face difficult situations. Memories of this type can improve self-esteem, or stimulate self-expression in public to sustain social bonds (Pietraszek-Kusik, 2015).

Other reminiscence therapy forms worth mentioning, used with patients living permanently in senior homes, are simulated contacts with the family (watching films, viewing photos) and a therapy with the use of dolls and soft toys. The observation conclusions indicate the improvement in the area of anxiety decrease and sleep time among the examined persons. For this method to be successful good relationship of the patient with the family, good sight and hearing and mild stage of dementia are required. (Zetteler, 2008).

\section{Music therapy}

Music therapy is a frequently discussed example of a therapy using reminiscence as well as elements of relaxation and movement therapies. Music therapists, in their clinical practice, use music as a means which effectively affects the treatment of various diseases and disorders as well as fosters the development of the patient's resources. Music therapists can use words, words with music or only music, which reflects multitasking nature of the music therapy (Rusowicz, 2017). How music stimulation influences perception in patients with Alzheimer's dementia 
was verified in the United States. Ten songs were selected for each patient taking into consideration previous preferences of the patient and the suggestions of the family. The patients participated in 3 to 7 sessions daily. It was observed that music auto-stimulation may bring benefits to the patients by improving their perception and engagement in therapeutic activities, which may lead to raising their reality awareness/orientation (Lancioni et al., 2013).

The other positive effects of music therapy was a result of „Singing for the Brain" Project of the Alzheimer Association for people with dementia and their caregivers. The therapy and the research were based on singing together. On the basis of the interviews with 20 participants and their caregivers it was stated that it helped in the improvement of relationship with other people, in the memory and mood improvement, better acceptance of the diagnosis and a stronger social integration. The above qualitative research showed how important the singing together was for the project participants (Osman, Tischler \& Schneider, 2016). Very interesting research on the effectiveness of music therapy in the treatment of Alzheimer's patients was conducted in Japan. The hypothesis was made that the music therapy can be an alternative substitute treatment for an unfavorable hormonal therapy because stimulation by music releases various biochemical substances and is strictly connected with steroid hormones, which, in turn, affect emotions and human behaviour (Fukui, Arai \& Toyoshima, 2012). The result of this research confirmed beneficial effect of music therapy on patients with dementia. It should be emphasised that this type of therapy may be used successfully by professional geragogists and therapists, both as a factor supporting other forms of therapy and as one of the basic elements of therapeutic procedures.

As research shows, music therapy modifies the components of the disease through sensory, cognitive, affective and behavioural effects. Receptive music therapy encourages cognitive stimulation, allowing patients to recall autobiographical memories and images (Guétin et al., 2009).

\section{Relaxation}

Beneficial influence of relaxation techniques used for the purposes of removing psychophysical tensions such as muscle relaxation and vegetative functions regulation cannot be ignored. The observations confirm that massage and touch relax the patients. The Japanese research shows significant effects of relaxation on people with dementia. The results suggest that progressive muscle relaxation improves the behavioural and psychological symptoms of dementia and activities of daily living lower the anxiety, apathy and irritability, in group home residents with dementia, but it does not affect their immune function (Ikemata \& Momose, 2017).

Deep breathing seems simple enough but taking time to practise it will help reduce tension, shortness of breath and anxiety. Yoga not only focuses on the body, helping strengthen muscles through a series of stretches and poses, but it 
also concentrates on deep breathing techniques, which is a fantastic way to relieve stress and tension. Visualisation, being similar to meditation, allows the patients to focus on a place that makes them feel relaxed, where they can de-stress and release any tension or anxiety they may be feeling. Touch can be an immensely powerful therapy - just think how much comfort we get from hugging each other. Therefore, massage can also be a useful therapy for someone with dementia (Fox, 2015).

Research shows that symptoms such as memory loss, lack of orientation, depression, addiction, anxiety, combativeness and anger, and sleeping disturbances can be contained or actually decreased through a course in a relaxation techniques (Verna, 2002).

\section{Validation therapy}

Working with patients using the validation therapy is based on the emotional aspect of communication. Its aim is to prompt proper social behaviour, decrease anxiety and fear level and the improve the patient's comfort. Naomi Feil, as a developer of the validation therapy distinguished four disorientation stages in patients with dementia as well as verbal and non-verbal interaction used at each of these stages. In the disorientation stages I and II, verbal techniques of communication with the patients are used. They consist in attentive listening to the patients and informing them which of their expressions make sense and are meaningful as well as learning the feelings of the patients, acknowledging them and ensuring the patients of their significance. Stages III and IV involve non-verbal techniques such as hugging, stroking or using properly selected elements of music therapy.

Sławiński (2017) illustrated the validation method in the following way: "Let us imagine that we are going slowly along the bank of a river. The river current carries a boat with our disoriented patient. We, using all means, try to convince him to anchor by the side where our reality is awaiting him: safe and firm ground under our feet, the house, warm bed, food. We try to show him all those "miracles" and convince him to return to the reality, to real life. The picture story goes on: our patient is not reacting to our calls, is not listening to what we are saying, He is not looking at us at all. He finds himself in the fog of oblivion. The river current carries him further, we both go ahead but still separately - along two parallel lines."

In order to meet him, we have no choice but get into the boat were the patient is. Only then do we have a chance to contact him, understand, help and accompany him. Validation assumes that we match our emotional levels.

The advantage of the validation method is the fact that it allows for consolation of the patients' emotions and improvement of their mood even when they seem to be functioning without any contact. 


\section{Occupational and physical therapy}

The aim of the occupational and physical therapy is to consolidate the skills still possessed by the patients, recreate those that have been lost lately and improve their general fitness. The occupational therapy consists in doing things the patient enjoyed in the past, i.e., drawing, painting, knitting, plant keeping, gardening and housework, etc. This method can be applied during group classes, however the best results can be achieved by engaging the patients in their house chores. The literature emphasises a great significance of this form of therapy as it satisfies psychological and social needs of the patient, maintains preserved skills, counteracts behaviour disorders and gives the patients the sense of "being needed". Worth mentioning is also the fact that this method is very easy to apply.

The activities conducted within the occupational therapy could be divided into individual:

- work simulation (sorting, arranging, vegetable and fruit peeling),

- manual (with the use of aids, making puzzles, shape matching),

- movement (walking, physical exercises),

- and group:

- movement (team games, dance),

- other activities (watching films, photographs together, reading aloud) (Ponichtera-Kasprzykowska, Pekala \& Sobów, 2013).

Hooghiemster and Eggermont (2012) published results of their research on patients with mild, recently diagnosed dementia, who had been doing a complex set of physical exercises (aerobic level exercises, improving agility and relaxation exercises) regularly, 3 times a week, for a period of 3 months. They noted a significant improvement in independent functioning (ADL Katz Index and Lawton Scale ${ }^{14}$ ). They also confirmed improvement inthe quality of life $(\mathrm{QoL})$ psychomotor speed. Also, Liberati and Raffone (2012) positively evaluated the effect of individually customized cognitive processes training on the patients' independence.

\section{Environmental therapy}

When people with dementia move to a nursing home, they are often unable to locate places, feel a sense of belonging, and orient themselves within the new unfamiliar setting. This results in a loss of autonomy, and also affects the quality of provided care. The transfer from one's home to a care facility can be stressful (Van Hoof, 2007). That is why it is recommended to let people with dementia stay in their environment for as long as they can.

14 Katz Index of Independence in Activities of Daily Living allows for the assessment of the patients' ability to function independently. The Lawton Scale assesses the person's ability to perform more complex activities of daily living. 
There are many different aspects of environmental therapy that can be provided at the patients' own home or at a nursing home.

The environmental therapy consists in creating a friendly and safe environment for the patient. The activities which we treat as environmental enhancements can be divided into two groups: 1) natural (e.g. access to a garden, park, forest), 2) simulated (looking at photographs of nature, of the patient's house, listening to natural sounds, aromatherapy (Ponichtera-Kasprzykowska et al., 2013). It should be remembered that in order to design safe environment for the patient the following guidelines shall be observed: 1) the layout of the whole building and rooms must be simple and clear, 2) the rooms must be clearly marked (e.g. bathroom), 3) they must be designed for the patients with mobility problems (e.g. rails).

The main argument in environmental therapy is that exposure to certain environmental conditions, such as natural and aesthetic amenities, can alleviate stress and promote physical and emotional well-being (Kaplan \& Kaplan, 1989; Hartig, Mang, \& Evans, 1991).

\section{Art therapy}

Art therapy, i.e. therapy through art, is an important element of therapy in various diseases and disorders. Positive effects of creative or artistic approaches to dementia care, support previous research on the use of such approaches in dementia care services (Rylatt, 2012). Further research on the immediate and longer-term outcomes and benefits of creative therapy for people with dementia is recommended to support the routine availability of such a therapy in dementia care (Mottram, 2003). It was also appreciated in case of patients with dementia, therefore, each nursing institution or rehabilitation centre provides artistic workshops where its patients can develop their creativity. The art therapy has a long history. It was used already at the end of 19th century by two French psychiatrists - A. A. Tardieu and M. Simon, but the notion itself - "art therapy" - was first used first by an English teacher Adrian Hill in 1942. It was Sigmund Freud (1972) who postulated a significant role of artistic creativity in the research of unconsciousness. In Poland, in the beginning of $2 \mathrm{O}^{\text {th }}$ century this method was analysed by a distinguished educator and ethicist - Stefan Szuman, and later by an oncologist from Kraków, J. Aleksandrowicz, who introduced this therapy to hospitals as a supplement for traditional treatment methods. It is very important for the patients with dementia to express their emotions through art of various forms (painting, drawing, cutting, sculpturing, etc.) as, while they are gradually losing contact with reality, art allows them to express their feelings, desires or their present mood. This is possible because creative activities sustain mobility, dexterity as well as spatial and constructive praxis. They also stimulate creative thinking. Moreover, because the art therapy is performed most frequently in groups, it helps in maintaining social contacts. 
Art therapy is not only visual or technical arts. It includes also choreography, i.e. dance therapy and movement therapy which, in general, enables integration of emotions and spirit with the body, releases from stress and allows the abandonment of old movement patterns and acquisition of new ones. Fairy-tale therapy (therapeutic fairy tales) and film therapy (Uler, 2019) are slightly different forms of art therapy, other than music therapy described above.

People who have dementia have problems with communication, cognition and memory, so engagement in art therapy allows for a different formand mode of communication. It allows patients to express their feelings. It activates part of their brain that they may not always activate such as creativity, visual-spatial, hand-eye coordination (Wanko, 2019).

Generally, the greatest advantage of art therapy is the fact that it is accessible for everyone regardless of their age - it can be used by children, adults and senior patients, it is cheap and easy to apply (Sobów, 2007).

\section{Self-Maintenance Therapy}

Self-Maintenance Therapy is an example of a complex non-pharmacological programme for people with dementia. It is a programme implemented by Dr Barbara Romeo, a German therapist of Polish origin. Its theoretical foundation is the concept of Self Maintenance Therapy, which values the optimal use of preserved skills by the patients through their participation in satisfactory everyday activities (Romeo and Eder, 1992). The main idea is to support the patient's sense of identity, through appropriate forms of communication (e.g. showing understanding to the patient without criticism and correction) and avoid failures. The concept of Self Maintenance Therapy comprises three areas: 1) medical treatment, including anti-dementia treatment, 2) rehabilitation programme for patients, 3) psycho-educational programme for caregivers. Self-Maintenance Therapy has an integrative character. It adapts methods of multiple concepts for its aims, such as art therapy or behavioural therapy, and, at the same time, it avoids using deficit-oriented training methods.

\section{Conclusion}

Dementagogy in the modern world is more and more important part of geragogy and special pedagogy, not only because societies are growing older but also because pharmacology should not be the only way of support. This article presents the most important non-pharmacological methods of supporting people with dementia. These methods improve life quality and preserve both physical and mental state. Particularly, it concerns memory training conducted in a friendly environment, properly selected occupational therapy, physical exercises, or elements of music therapy (Długosz-Mazur, Bojar, \& Gustaw, 2013). 
Research proves effectiveness of non-pharmacological interventions with dementia patients. It is recommended by therapeutic guidebooks as first choice procedures for the majority of patients, but the results ofthe research on physicians' practice and clinician's everyday experience shows that it is used relatively rarely (Vasse, 2012).

It seems that there are several reasons for this state of things. The majority of decision makers expect a prompt and effective treatment results, and non-pharmacological methods that require more time, regularity and coordinated actions, seem to be ineffective. Undoubtedly, the additional problem is also the lack of knowledge among health care workers, lack of information and family educators who could present the complex non-pharmacological offer and direct the family. And here the door opens for dementagogy and educators specialising in non-pharmacological methods of support provided for people with dementia and their families.

\section{References}

Bachman, W. (1990). Geragogika jako kompleks zadań pedagogiki specjalnej. Edukacja, 1.

Borzym, A. (2010). Oddziaływania niefarmakologiczne w otępieniu. In T. Parnowski (Ed.). Choroba Alzheimera (pp. 49-51). Warszawa: Wydawnictwo Lekarskie PZWL.

DSM IV (2012). Kryteria diagnostyczne według DSM-IV-TR. Wrocław: Urban \& Partner.

Długosz-Mazur, E., Bojar, I., \& Gustaw, K. (2013). Niefarmakologiczne metody postępowania u chorych z otępieniem. Medycyna Ogólna i Nauki o Zdrowiu, $19(4), 458-462$.

Fox, H. (2015). What relaxation techniques and therapies are good for dementia care? Live better with dementia. Retrieved from: https://dementia.livebetterwith.com/blogs/advice/what-relaxation-techniques-and-therapies-are-good-for-dementia-care (2019.10.24).

Freud, S. (1972). The psychopathology of everyday life of Sigmund Freud. New York: W. W. Norton.

Fukui, H., Arai, A., \& Toyoshima, K. (2012). Efficacy of Music Therapy in Treatment for the Patients with Alzheimer's Disease. International Journal of Alzheimer's Disease, 10.

Guétin, S., Portet, F., Picot, M.C., Pommié, C., Messaoudi, M., Djabelkir, L., Olsen, A.L., Cano, M.M., Lecourt, E., \& Touchon, J. (2009). Effect of Music Therapy on Anxiety and Depression in Patients with Alzheimer's Type Dementia: Randomised, Controlled Study. Dement Geriatr Cogn Disord, 28, 36-46. DOI: 10.1159/000229024

Hartig, T., Mang, M., \& Evans, G. W. (1991). Restorative effects of natural environment experiences. Environment and behavior, 23 (1), 3-26. 
Hasomed (2012). Komputerowo wspomagana rehabilitacja chorych z zaburzeniami funkcji poznawczych. Retrieved from: Rehacom, https://www.biomed.org.pl/ materialy/_upload/KATOLOGIiFOLDERY/Katalog_RehaCom_2012_web_m. pdf (2019.04.09).

Hooghiemstra, A., \& Eggermont, L. (2012). Study protocol: Exercise and cognition in sedentary adults with early-onset dementia. BMC Neurol, 16, 12-75.

Ikemata, Sh., Momose, Y. (2017). Effects of a progressive muscle relaxation intervention on dementia symptoms, activities of daily living, and immune function in group home residents with dementia in Japan. Jpn J Nurs Sci, 14(2), 135-145. Retrieved from: https://www.ncbi.nlm.nih.gov/pmc/articles/PMC5396310/ (2019.10.15)

Kaplan, R., \& Kaplan, S. (1989). The experience of nature: A psychological perspective. CUP Archive.

Kaplan, H., Sadock B., \& Sadock, V. (2001). Psychiatria kliniczna. Wrocław: Wydawnictwo Medyczne Urban \& Partner.

Kłoszewska, I. (2012). Niefarmakologiczne postępowanie w otępieniu. In: Diagnostyka i leczenie otępień. Rekomendacje zespołu ekspertów Polskiego Towarzystwa Alzheimerowskiego. Medisfera, pp. 106-108.

Lancioni, G., O’Reilly, M., Singh, N., Sigafoos, J., Grumo, G., Pinto, K., Stasolla, F., Signorino, M., \& Groeneweg, J. (2013). Assessing the impact and social perception of self-regulated music stimulation with patients with Alzheimer's disease. Research in Developmental Disabilities, 34, 139-146.

Liberati, G., \& Raffone, A. (2012). Cognitive reserve and its implication for rehabilitation and Alzheimer's disease. Cogn Process, 1 (1), 1-12.

Mottram, P. (2003). Art Therapy with Clients Who have Dementia. Art Therapy Service, Manchester Mental Health and Social Care Trust, 2(2), 272-277. DOI: https://doi.org/10.1177/1471301203002002010.

Osman, S., Tischler, V., \& Schneider, J. (2016). 'Singing for the Brain': A qualitative study exploring the health and well-being benefits of singing for people with dementia and their carers. Dementia, 15(6), 1326-1339.

Pietraszek-Kusik, H. Demencja. metody oddziaływań pozafarmakologicznych. Retrieved from: http://www.przeglad.amp.edu.pl/uploads/2015/1/28_1_42_2015. pdf (10.04.2019).

Ponichtera-Kasprzykowska, M., Pękala, K., \& Sobów, T. (2013). Niefarmakologiczne strategie postępowania w zaburzeniach zachowania towarzyszących otępieniu. Aktualności Neurolologiczne, 13(4), 304.

Relaxation Techniques for People with Dementia. Retrieved from: https://www. active-minds.org/news/relaxation-techniques-for-people-with-dementia/ (2019.10.24).

Romeo, B., \& Eder, G. (1992). Selbst-Erhaltungs-Terapie (SET): Konzept einer neuropsychologischen Therapiebei Alzheimer-Kranken. Gerontopsychologie und Psychiatrie, 4, 267-282. 
Rusowicz, J. (2017). Muzykoterapia w chorobie Alzheimera. Polskie Pismo Muzykoterapeutyczne, 4, 32-33.

Romero B. SET Institute (2019). Retrieved from: http://www.set-institut.de/Strona_ polska/body_strona_polska.html (10.04.2019).

Rylatt, P. (2012). The benefits of creative therapy for people with dementia. Nursing Standard, 26(33), 42-47.

Sławiński, L. (2017). Terapia walidacyjna czy łączenie z rzeczywistością. Retrieved from: https://prezi.com/w3do1wphvk-3/terapia-walidacyjna-czy-aczenie-z-rzeczywistoscia/ (10.04.2019).

Sobów, T. (2007). Zasady postępowania terapeutycznego w zespołach otępiennych. Przegląd Neurologiczny, 3.

Steurenthaler, J. (2012). Dementagogik: Dementiell erkrankten Menschen neu und ganzheitlich begegnen, Springer VS College, 6.

Szarota, Z. (2014). Edukacja dorosłych w Polsce i na świecie. Edukacja Ustawiczna Dorostych, 1(84), 13.

Uler, M. Arteterapia-na czym polega lecznicza moc sztuki? Retrieved from: https:// www.poradnikzdrowie.pl/psychologia/zdrowie-psychiczne/arteterapia-na-czym-polega-lecznicza-moc-sztuki-aa-UF78-1hoE-iYKP.html (2019.05.15).

Van Hoof, J., \& Kort, H. S. (2009). Supportive living environments: a first concept of a dwelling designed for older adults with dementia. Dementia, 8(2), 293-316.

Vasse, E., Vermooij-Dassen, M., Cantegreil, I. \& al. (2012). Guidelines for psychosocial interventions in dementia care: a European survey and comparison. Int. J. Geriatr. Psychiatry, 27, 40-48.

Verna, S. M. (2002). Effectiveness of a relaxation technique to decrease the memory and behavior problems of Alzheimer 's patients. Walden University ScholarWorks. Retrieved from: https://pdfs.semanticscholar.org/f6db/d718aoa co9d2fba689cdd35fo2c8bfd94737.pdf (2019.10.24).

Wanko, L. (2019). Art therapy helps dementia patients communicate and connect. Retrieved from: https://www.njtvonline.org/news/video/art-therapy-helps-dementia-patients-communicate-and-connect/ (2019.10.15).

WHO. Retrieved from: https://www.who.int/mental_health/neurology/dementia/ en/ (27.02.2019).

Zetteler, J. (2008). Effectiveness of simulated presence therapy for individuals with dementia: a systematic review and meta-analysis. Aging Ment. Health, 12, $779-785$.

Zych, A. (2014). Pedagogika osób z otępieniem jako nowy obszar geragogiki specjalnej. Labor et Educatio, 2, 271-283. 


\section{DEMENTAGOGIKA - NIEFARMAKOLOGICZNE FORMY POMOCY OSOBOM Z OTĘPIENIEM}

Streszczenie: Artykuł przedstawia stosunkowo nowy dział pedagogiki - dementagogikę. Celem poznawczym artykułu jest wskazanie nowych obszarów badań w zakresie pedagogiki specjalnej, odnoszących się do dementagogiki. Starzenie się społeczeństw stawia nowe wyzwanie przed naukowcami, także z zakresu pedagogiki. Pomoc osobom z demencją należy do wyjątkowych wyzwań, a także jest ogromną szansą na znalezienie niefarmakologicznych sposobów pomocy. Głównym celem dementagogiki jest towarzyszenie osobie $\mathrm{z}$ demencją $\mathrm{w}$ procesie bolesnego rozstania ze sobą i wspieranie tej osoby $\mathrm{w}$ trudnym procesie choroby. W artykule znajdują się wybrane niefarmakologiczne metody wspierania pacjentów $\mathrm{z}$ otępieniem, takie jak terapia poznawcza, rehabilitacja, terapia reminiscencyjna, muzykoterapia, relaksacja, terapia walidacyjna, terapia zajęciowa i ruchowa, terapia środowiskowa.

Słowa kluczowe: dementagogika; geragogika specjalna; otępienie; pomoc osobom starszym; Alzheimer; terapia; niefarmakologiczne metody wsparcia.

Małgorzata Banasiak - doktor pedagogiki, pracownik socjalny, psycholog, zatrudniona na stanowisku adiunkta w Katedrze Dydaktyki i Mediów w Edukacji Wydziału Filozofii i Nauk Społecznych Uniwersytetu Mikołaja Kopernika w Toruniu. Adres e-mail: malfran@umk.pl.

Agata Wołowska - doktor psychologii, zatrudniona na stanowisku adiunkta w Katedrze Dydaktyki i Mediów w Edukacji Wydziału Filozofii i Nauk Społecznych Uniwersytetu Mikołaja Kopernika w Toruniu. Adres e-mail: ataw@umk.pl. 